\section{A Convenient and Reliable Method to Evaluate Blueberry Pollen Viability}

\author{
Yuehe Huang $^{1}$ and Charles E. Johnson ${ }^{2}$ \\ Department of Horticulture, Louisiana Agricultural Experimental Station, \\ Louisiana State University, Baton Rouge, LA 70803
}

Additional index words. Vaccinium corymbosum, pollen quality, enzymatically induced fluorescence

Three common methods for testing pollen quality are in vivo, in vitro germination, and histochemical. The disadvantages of these methods were reviewed by Abdul-Baki (1992). The advantage of the fluorescein diacetate (FDA) procedure is that pollen viability is determined based on the plasmalemma integrity of the vegetative cell (Heslop-Harrison and Heslop-Harrison, 1970). This method has been proven to be convenient and reliable to evaluate pollen viability (Abdul-Baki, 1992; Sahar and Spiegel-Roy, 1984). Blueberry pollen viability has been determined by staining procedures (Cockerham and Galleta, 1976; Megalos and Ballington, 1987) and in vitro germination methods (Brewer and Dobson, 1969; Goldy and Lyrene, 1983; Lang and Parrie, 1992). The objective of this study was to examine the effectiveness of the FDA procedure in determining the viability and germination of blueberry pollen.

Six-year-old 'O'Neal', 'Gulfcoast', and 'Sharpblue' plants were moved in Jan. 1995 from a lathhouse into temperature-controlled storage $\left(0^{\circ} \mathrm{C}\right)$. After 3 weeks, plants were forced to flower in a growth chamber $\left(25^{\circ} \mathrm{C}\right.$ day/16 ${ }^{\circ} \mathrm{C}$ night, $12-\mathrm{h}$ photoperiod). Pollen was collected from flowers of the same physiological age ( $24 \mathrm{~h}$ after opening of the corolla) at various shoot locations. Pollen viability was evaluated at collection and after 8 months of storage in a sealed vial at $0{ }^{\circ} \mathrm{C}$. The culture medium was prepared as described by Lang and Parrie (1992) with some modifications. It contained $2.5 \%$ ultrapure agar, $0.29 \mathrm{M}$ sucrose, $1.62 \times 10^{-3} \mathrm{M} \mathrm{H}_{3} \mathrm{BO}_{3}, 1.69 \times 10^{-3} \mathrm{M}$ $\mathrm{Ca}\left(\mathrm{NO}_{3}\right)_{2} \cdot 4 \mathrm{H}_{2} \mathrm{O}, 8.11 \times 10^{-4} \mathrm{M} \mathrm{MgSO}_{4} \cdot 7 \mathrm{H}_{2} \mathrm{O}$, $9.89 \times 10^{-4} \mathrm{M} \mathrm{KNO}_{3}$, and $0.01 \%$ FDA (Sigma, St. Louis). The same medium, without FDA, was used for the control ( $\mathrm{pH}$ 5.4). A thin layer of the medium was transferred onto a microscope slide by dipping the slide into the hot liquid medium, withdrawing the slide quickly, and placing it on a glass plate horizontally until an even film developed. Pollen was dusted uniformly, with a camel hair brush, onto a slide containing the culture medium. The slide

Received for publication 8 Mar. 1996. Accepted for publication 5 Aug. 1996. Louisiana Agricultural Experiment Station manuscript no. 96-28-0072. The cost of publishing this paper was defrayed in part by the payment of page charges. Under postal regulations, this paper therefore must be hereby marked advertisement solely to indicate this fact.

${ }^{1}$ Research Associate

${ }^{2}$ Professor. was kept in a plastic storage box lined with moist paper towels and was held in a growth chamber $\left(25^{\circ} \mathrm{C}\right)$. Pollen viability was evaluated using two standards: percent fluorescing pollen and percent germinated pollen (AbdulBaki, 1992). After 90 min incubation, percent fluorescing pollen was determined and photographs were taken under a light microscope with an ultraviolet source provided by a mercury lamp. Percent germinated pollen was determined after $8 \mathrm{~h}$ incubation. Each determination was obtained by randomly counting 250 to 350 pollen tetrads at six to 10 locations in a single slide. A pollen grain was considered to have germinated when the length of the pollen tubes was at least as large as the diameter of the pollen tetrad. The experiment was a completely randomized design with four replications. Data were subjected to analysis of variance, and mean separations were conducted by Duncan's multiple range test.

A small portion of pollen grains began to fluoresce after 30 min incubation; maximum fluorescing occurred at $90 \mathrm{~min}$. Some grains of 'O'Neal' and 'Gulfcoast' pollen began to germinate at $45 \mathrm{~min}$, and $>70 \%$ of grains showed pollen tubes at $90 \mathrm{~min}$ incubation. However, 'Sharpblue' pollen did not start to germinate until 90 min incubation. Maximum germination for all was observed after $8 \mathrm{~h}$ incubation. Therefore, percent fluorescing pollen and percent germinated pollen were determined $90 \mathrm{~min}$ and $8 \mathrm{~h}$ after incubation, respectively.

Pollen tetrads from 'O'Neal' and 'Gulfcoast' produced stronger fluorescence, started to germinate earlier, and had a faster apparent pollen tube growth rate than 'Sharpblue' (data not shown), indicating that pollen tetrads from 'O'Neal' and 'Gulfcoast' are more vigorous than those from 'Sharpblue'.

Pollen germination and pollen tube growth were similar to pollen germinated on FDAfree medium (data not shown). Ultrapure agar medium with $0.01 \%$ FDA resulted in good germination percentages and pollen tube growth. These findings indicated that ultrapure agar and FDA have no adverse effects on blueberry pollen viability. Percent fluorescing pollen was well correlated with percent germinated pollen for fresh and stored pollen (Table 1 ), indicating that the fluorescing procedure was a reliable evaluation of blueberry pollen viability. Pollen stored under refrigeration for 8 months had no significant loss in fluorescing and germination percentages, indicating that blueberry pollen can be easily stored for a long time without significantly losing viability.
The ability of pollen grains to perform fertilization within the embryo sac is a reasonable measure of pollen viability. However, the assessment is time-consuming and not always feasible (Heslop-Harrison et al., 1984). The fluorochromatic reaction procedure we tested provides a satisfactory measure of pollen viability. Hydrolysis of FDA by esterase results in the intracellular accumulation of fluorescein, which is diffused back into the medium only if the cell membrane is damaged. In this study, no fluorescence was detected in the agar medium when the test was conducted at 90 min after incubation. The results presented here support the other findings that blueberry pollen could be stored near $0^{\circ} \mathrm{C}$, possibly up to 1 year, without serious loss of fertility (Galleta, 1975).

\section{Literature Cited}

Abdul-Baki, A.A. 1992. Determination of pollen viability in tomatoes. J. Amer. Soc. Hort. Sci. 117:473476.

Brewer, J.W. and R.C. Dobson, 1969. Pollen analysis of two highbush blueberry varieties Vaccinium corymbosum. J. Amer. Soc. Hort. Sci. 94:251-252.

Cockerham, L.E. and G.J. Galleta. 1976. A survey of pollen characteristics in certain Vaccinium species. J. Amer. Soc. Hort. Sci. 101:671-676.

Galletta, G.J. 1975. Blueberries and cranberries, p. 154-196. In: J. Janick and J.N. Moore (eds.). Advances in fruit breeding. Purdue Univ. Press, West Lafayette, Ind.

Goldy, R.G. and P.M. Lyrene. 1983. Pollen germination in interspecific Vaccinium hybrids. HortScience 18:54-55.

Heslop-Harrison, J., Y. Heslop-Harrison, and K.R. Shivanna. 1984. The evaluation of pollen quality and a further appraisal of the fluorochromatic (FCR) test procedure. Theor. Appl. Genet. 67:367-379.

Heslop-Harrison, J. and Y. Heslop-Harrison. 1970. Evaluation of pollen viability by enzymatically induced fluorescence; intracellular hydrolysis of fluorescein diacetate. Stain Techn. 45:115-120.

Lang, G.A. and E.J. Parrie. 1992. Pollen viability and vigor in hybrid southern highbush blueberries (Vaccinium corymbosum L.). HortScience 27:425427.

Megalos, B.S. and J.R. Ballington. 1987. Pollen viability in five southeastern United States diploid species of Vaccinium. J. Amer. Soc. Hort. Sci. 112:1009-1012.

Sahar, N. and P. Spiegel-Roy. 1984. In vitro germination of avocado pollen. HortScience 19:886-888.

Table 1. Comparison of fluorescing percentages with germination percentages of fresh and stored pollen derived from three southern highbush blueberry cultivars.

\begin{tabular}{lcc}
\hline & \multicolumn{2}{c}{ Pollen characteristic } \\
\cline { 2 - 3 } Cultivar & $\begin{array}{c}\text { Fluorescing (Y) } \\
(\%)\end{array}$ & $\begin{array}{c}\text { Germination }(\mathrm{X}) \\
(\%)\end{array}$ \\
\hline \multicolumn{3}{c}{ Fresh pollen } \\
O'Neal & $91.8 \mathrm{a}$ & $93.0 \mathrm{a}$ \\
Gulfcoast & $92.8 \mathrm{a}$ & $89.6 \mathrm{a}$ \\
Sharpblue & $82.5 \mathrm{~b}$ & $81.7 \mathrm{~b}$ \\
\multicolumn{3}{c}{} \\
O'Neal & Pollen stored for 8 months \\
Gulfcoast & $90.1 \mathrm{a}$ & $91.8 \mathrm{a}$ \\
Sharpblue & $88.9 \mathrm{a}$ & $90.1 \mathrm{a}$ \\
Y=3.719 & $77.9 \mathrm{~b}$ & $78.5 \mathrm{~b}$ \\
\hline
\end{tabular}

${ }^{\mathrm{z}}$ Means separation within pollen type by Duncan's multiple range test, $P \leq 0.05$. 